\title{
GENETIC AND ENVIRONMENTAL EFFECTS ON FOETAL AND PLACENTAL GROWTH IN MICE
}

\author{
ANNE MaLAREN \\ A.R.C. Unit of Animal Genetics, Institute of Animal Genetics, \\ Edinburgh 9
}

(Received 15th June 1964)

Summary. Inbred (C57BL $\left.\$ \times \mathrm{C}_{57} \mathrm{BL}_{\delta}{ }^{*}\right)$ and $\mathrm{F}_{1}$ hybrid $(\mathrm{C} 57 \mathrm{BL} q \times$ $\mathrm{C} 3 \mathrm{H}_{\delta}$ ) litters were compared with respect to (a) birth weight, (b) foetal weight at $17 \frac{1}{2}$ days' gestation, (c) placental weight at the same stage. $F_{1}$ hybrids were heavier than inbred young at birth, but not to any significant extent at $17 \frac{1}{2}$ days. Placentae in $F_{1}$ litters were nearly $20 \%$ heavier than those in inbred litters.

Other factors examined were the number of young in the litter and in the uterine horn, and the position of implantation within the uterine horn. Birth weight and foetal and placental weight at $17 \frac{1}{2}$ days' gestation were all inversely related to the number of young in the litter. The effect on placental growth was systemic, i.e. it was not affected by the distribution of implantations between uterine horns. There was a suggestion of a systemic effect on foetal growth, in addition to a significant local effect exerted by the other implantations in the same horn. When allowance was made for the number in the litter, those litters distinguished by higher mean placental weight did not necessarily have large foetuses. But within a female, the horn containing the heavier placentae on average had heavier foetuses too, allowance again being made for the number of implantations. Within the uterine horn also, foetal and placental weight showed a positive association. Since there was no genetic heterogeneity among litter-mates, this association suggests a causal dependence of foetal growth on placental size.

The mean weight of foetuses and placentae decreased from the ovarian towards the cervical end of the uterine horn. This effect was most marked for placentae. Foetal growth was not affected directly by position in the uterine horn, but reflected the gradient in placental growth.

It is argued that haemodynamic factors are responsible (i) for the effect of position in the horn on placental growth, and hence on foetal growth, and (ii) for the systemic effect of number in the litter on foetal and placental growth. But the local effect of other foetuses in the same horn on foetal growth seems more likely to be a result of mechanical pressure arising from the distension of the uterus. 


\section{INTRODUCTION}

Variation in foetal growth may be associated with genetic or environmental factors that vary either from litter to litter, or from foetus to foetus within a single litter. The possibilities may be summarized (McLaren \& Michie, 1960a) as follows:

1. Litter factors (acting on the litter, or at least on the uterine horn as a whole) A. Genetic. (i) Mother's genotype (for an elegant analysis of the influence of maternal genotype on foetal growth, in mice, see Brumby, 1960). (ii) Foetal genotype (genetic factors shared by all the members of the litter).*

B. Environmental. (i) Maternal (including mother's age, parity, nutritional status and conditions of life). (ii) Direct (for example, the number of foetuses in the litter or in the uterine horn.)*

2. Individual factors (singling out individuals within the litter)

A. Genetic (segregating major or minor genes with effects on growth; for references, see Grüneberg, 1952).

B. Environmental (position in the uterine horn).*

From the point of view of growth, the most important element in the environment of a foetus is presumably its placenta. Once established, the chorioallantoic placenta is responsible in mice for the entire transfer of nutrients from the mother to the foetus. Whether the size of the placenta affects foetal growth has not been clearly established in any species (for references, see McCance, 1962); but to the extent that it does, we need to shift our attention away from the regulation of foetal growth, and focus it instead upon placental growth. All the possible causes of variation listed above may affect placental growth as well as foetal growth, with the additional complication that genetically, the placenta is of dual origin, part foetal and part maternal.

McLaren \& Michie (1959a) reported that position of implantation within the uterine horn influenced foetal weight; Healy, McLaren \& Michie (1960) found that foetal weight was affected by the presence of other foetuses, especially if these were in the same, rather than in the opposite, uterine horn. Foetuses dying in mid-pregnancy exerted effects upon the growth of the survivors comparable to those exerted by other surviving foetuses. Whether any of these effects were exerted via the placenta, rather than directly on the foetus, could not be ascertained since placental weights were not taken.

The present study is concerned with the effect on foetal and placental growth of three factors only, representing three categories (marked with an asterisk) of the six listed above: two environmental variables, namely the number of foetuses in the litter or uterine horn, and their position within the uterine horn; and one difference of foetal genotype affecting whole litters, namely whether the litter consists of inbred or $F_{1}$ hybrid young. As far as possible, variations in the remaining three categories were eliminated. Maternal genotype was standardized by using females of a single inbred strain (C57BL); females were mated to males of their own or another inbred strain $(\mathrm{C} 3 \mathrm{H})$ so that there should be a minimum of genetic segregation within litters; all females used were 
young adults which had not previously borne litters. Conditions of management and nutrition were kept as constant as possible.

\section{MATERIAL AND METHODS}

All females belonged to the $\mathrm{C} 57 \mathrm{BL} / \mathrm{McL}$ inbred strain. They were paired with males either from their own strain or from the $\mathrm{C} 3 \mathrm{H} / \mathrm{BiMcL}$ inbred strain, and examined each morning for copulation plugs. Females with copulation plugs

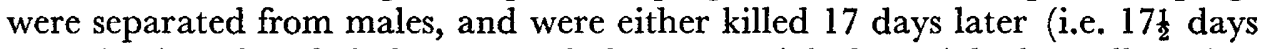
post coitum) so that their foetuses and placentae might be weighed, or allowed to give birth. The litters from the two types of mating will be referred to as inbred

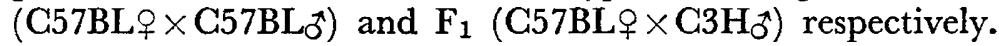

At autopsy, the uterus was opened, and the number of live foetuses in each uterine horn was recorded. Any failed implantations were identified as early, middle or late deaths (McLaren \& Michie, 1959b), and their number and relative positions were recorded. Each foetus was removed from the embryonic membranes, separated from its umbilical cord, blotted lightly on filter paper, and weighed to the nearest centigram. Each placenta was separated from its umbilical cord, and, as far as possible, from the embryonic membranes, but not from the decidua basalis; it was then blotted lightly on filter paper, and weighed to the nearest milligram. No detectable loss of weight from dehydration was suffered either by foetuses or placentae during this procedure.

Before analysing the data, foetal weights were converted into log decigrams, and placental weights into log centigrams. In analysing variation between litters, or between uterine horns, the mean of the log weights for the litter or horn was taken. These means were not weighted according to the number of foetuses present, because variation within the uterine horn tends to rise as the number of foetuses increases (Healy et al., 1960), and the amount of information on the mean contributed by a horn does not therefore depend very greatly on the number of foetuses in the horn.

The females which were allowed to continue to term were inspected each morning to see if the litter had been born. Each newborn litter was weighed as a whole to the nearest centigram, and the logarithm of the mean individual weight was taken as the unit of analysis.

\section{RESULTS}

\section{BIRTH}

Twenty-one inbred and twelve $F_{1}$ hybrid litters were weighed at birth. For the inbred mice, the mean number in the litter was 6.4 and the mean birth weight $1.26 \mathrm{~g}$; for $\mathrm{F}_{1}$ hybrids, the corresponding figures were 6.7 and $1.34 \mathrm{~g}$. As has been recorded on numerous occasions since the early work of Gates (1924), birth weight was strongly dependent on number in the litter (Text-fig. 1); the analysis of variance is given in Table 1. The slope of the regression line was less steep for the inbred than for the $F_{1}$ litters: this effect was significant at the $5 \%$ level. When the mean birth weight in each group had been adjusted (using the appropriate regression coefficient) to the common mean litter size 
of 6.5 , the $F_{1}$ young proved to be significantly heavier than the inbred young $(P<0.001)$.

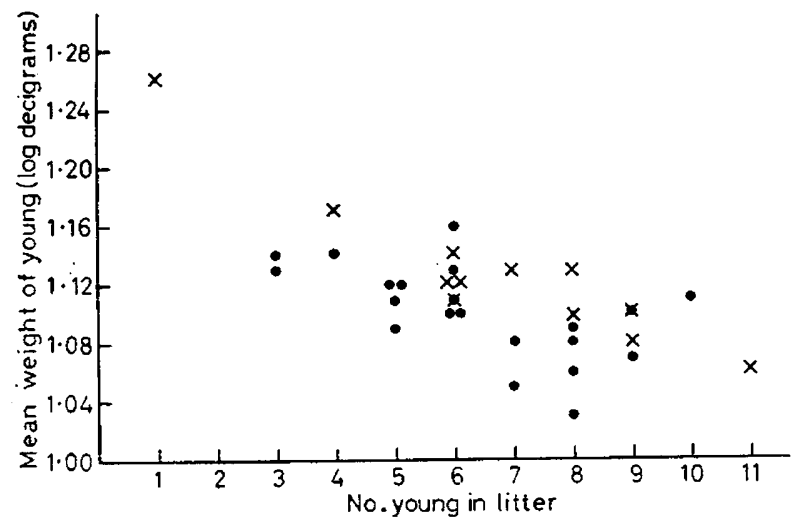

TEXT-FIG. 1. Relation of mean birth-weight to litter size in inbred $(\circlearrowleft)$ and $\mathbf{F}_{1}$ hybrid $(x)$ litters. Each point represents one litter.

TABLE 1

COMPARISON OF THE REGRESSION OF MEAN BIRTH WEIGHT ON NUMBER IN THE LITTER FOR INBRED AND F1 HYBRID YOUNG

\begin{tabular}{|c|c|c|c|c|}
\hline Source of variation & $d . f$. & $\begin{array}{c}\text { Mean square } \\
\left(\times 10^{3}\right)\end{array}$ & $F$ & $P$ \\
\hline $\begin{array}{l}\text { Inbred } \\
\text { Regression } \\
\text { Residual }\end{array}$ & $\begin{array}{r}1 \\
19\end{array}$ & $\begin{array}{l}7 \cdot 26 \\
0 \cdot 70\end{array}$ & $10 \cdot 35$ & $<0.01$ \\
\hline $\begin{array}{l}\mathbf{F}_{1} \text { hybrid } \\
\text { Regression } \\
\text { Residual }\end{array}$ & $\begin{array}{r}1 \\
10\end{array}$ & $\begin{array}{r}24.55 \\
0.37\end{array}$ & $65 \cdot 9$ & $<0.001$ \\
\hline $\begin{array}{l}\text { Comparison } \\
\text { Difference between slopes } \\
\text { Combined residual }\end{array}$ & $\begin{array}{r}1 \\
29\end{array}$ & $\begin{array}{l}2 \cdot 59 \\
0.59\end{array}$ & $4 \cdot 41$ & $<0.05$ \\
\hline
\end{tabular}

The regression coefficient for inbred litters is $-0.010 \log 10$ units, for $F_{1}$ hybrid litters $-0.018 \log _{10}$ units.

$17 \frac{1}{2}$ DAYs' GESTATION

Sixty-six females were killed at $17 \frac{1}{2}$ days' gestation: thirty of these were carrying inbred and thirty-six $F_{1}$ hybrid litters. One inbred litter consisted of seven implantations in one uterine horn and none in the other; it was omitted, since it could throw no light on the relative effect on foetal and placental growth of implantations in the same versus the opposite horn. The mean foetal weights in the remaining sixty-five litters are shown in Text-figs. 2 and 3 . The foetuses in two of the $F_{1}$ hybrid litters (Text-fig. 3 ) were very small, and their developmental age appeared to be less than $17 \frac{1}{2}$ days. Possibly implantation in these females was delayed. The two litters, which are statistical 'outliers' by the criteria of Dixon (1953), have been omitted from subsequent computations. Twenty-nine 


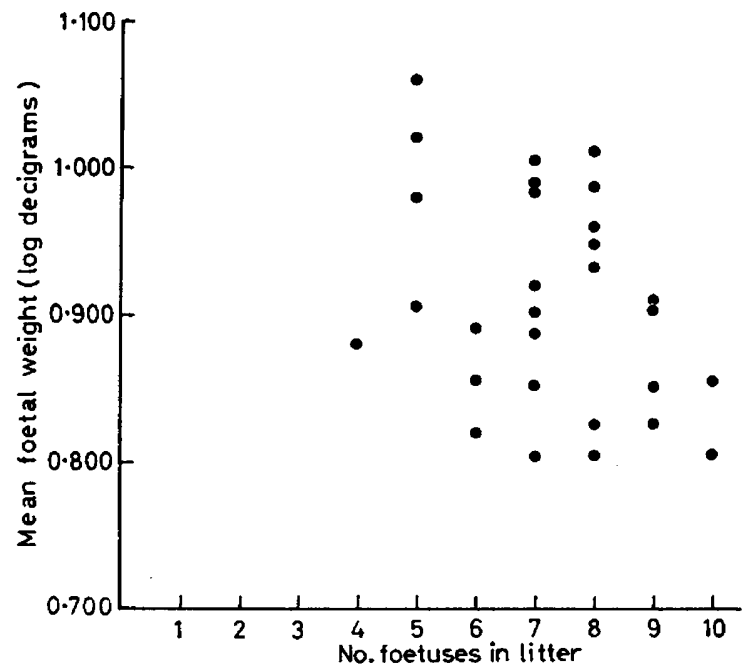

Text-pIG. 2. Relation of mean foetal weight at $17 \frac{1}{2}$ days' gestation to number of foetuses in the litter. Each point represents one inbred litter.

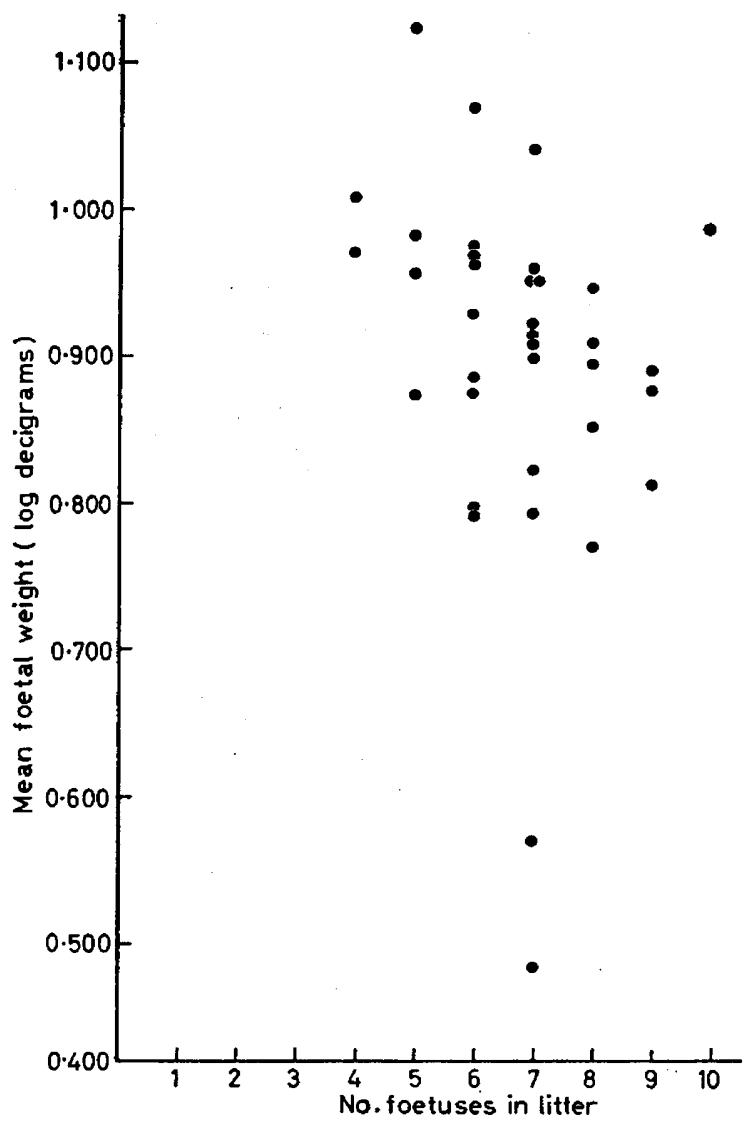

TExT-Fic. 3. Relation of mean foetal weight at $17 \frac{1}{2}$ days' gestation to number of foetuses in the litter. Each point represents one $\mathbf{F}_{1}$ hybrid litter. 
inbred and thirty-four $F_{1}$ hybrid litters were therefore available for further analysis.

\section{Embryonic mortality}

More implantations failed in the inbred than in the $F_{1}$ hybrid litters (Table 2 , but the difference is not statistically significant. Early deaths accounted for $9 \%$ of all implantations; middle and late deaths together for less than $1 \%$.

The placentae of the late death and of two of the middle deaths were weighed. The placenta of one of the middle deaths was heavier than the average for the litter; the other two placentae were the smallest in their respective litters, but not strikingly so; that is, their weights lay within the normal range of variation (Dixon, 1953) for those litters.

\section{TABLE 2}

NUMBERS OF LIVE FOETUSES AND FAILED IMPLANTATIONS IN INBRED AND F1 HYBRID LITTERS

\begin{tabular}{|c|c|c|c|c|c|c|c|c|c|}
\hline & \multirow{3}{*}{$\begin{array}{c}\text { No. } \\
\text { litters }\end{array}$} & \multicolumn{4}{|c|}{ L. horn } & \multicolumn{4}{|c|}{ R. horn } \\
\hline & & \multicolumn{3}{|c|}{ Deaths } & \multirow{2}{*}{ Live } & \multicolumn{3}{|c|}{ Deaths } & \multirow{2}{*}{ Live } \\
\hline & & Early & Middle & Late & & Early & Middle & Late & \\
\hline $\begin{array}{l}\text { Inbred } \\
\text { F1 hybrid }_{1}\end{array}$ & $\begin{array}{l}29 \\
34\end{array}$ & $\begin{array}{l}9 \\
9\end{array}$ & $\begin{array}{l}1 \\
0\end{array}$ & $\begin{array}{l}1 \\
0\end{array}$ & $\begin{array}{r}95 \\
115\end{array}$ & $\begin{array}{r}17 \\
9\end{array}$ & $\begin{array}{l}2 \\
0\end{array}$ & $\begin{array}{l}0 \\
0\end{array}$ & $\begin{array}{l}120 \\
114\end{array}$ \\
\hline
\end{tabular}

The distribution of early deaths between litters was analysed to see whether early failure was the result of individual or of litter factors. Since the expected number of early deaths per litter is small (less than one), the usual distribution of $\chi^{2}$ will overestimate the heterogeneity of the data. A closer approach to a normal deviate can be obtained by calculating Haldane's (1945) statistic $\xi$. For the present data $\xi$ has the value $1 \cdot 75$, which corresponds to $P \simeq 0 \cdot 08$. There is therefore no significant evidence that early failure is due to inadequacies of the maternal evironment.

Runts

The foetal and placental weights in each uterine horn were examined for the presence of runts (McLaren \& Michie, 1960a). The criteria of Dixon (1953) for $\alpha=0.01$ were used; that is, only those values which would have been expected to occur by chance in less than one in a hundred uterine horns were counted as runts. Two runt foetuses were found, one in an inbred and one in an $F_{1}$ litter; details of the foetal and placental weights are given in Table 3. Neither of the runt foetuses was associated with a runt placenta, though the placenta of one was the smallest in the horn. Indeed no runt placentae occurred in any of the uterine horns.

\section{Effect of genotype and number in litter}

Foetal weight. The mean weight of the live foetuses in each inbred and $F_{1}$ hybrid litter is shown in Text-figs. 2 and 3. Litters are arranged according to 
the number of live foetuses rather than the total number of implantations, since Healy et al. (1960) showed that implantations which fail early have no effect on the growth of the survivors, while in the present study middle and late deaths are so rare that they may be ignored. In Text-fig. 4 the data (omitting the two anomalous $F_{I}$ hybrid litters) are grouped according to the number of foetuses in the litter, and Table 4 gives the corresponding analysis of variance.

TABLE 3

FOETAL AND PLACENTAL WEIGHTS FOR THE TWO UTERINE HORNS CONTAINING RUNTS

\begin{tabular}{|c|c|c|c|c|c|c|}
\hline & \multicolumn{3}{|c|}{ Uterine horn 1 (inbred) } & \multicolumn{3}{|c|}{ Uterine horn $2\left(F_{1}\right)$} \\
\hline & & $\begin{array}{c}\text { Foetus } \\
(\mathrm{g})\end{array}$ & $\begin{array}{l}\text { Placenta } \\
(\mathrm{g})\end{array}$ & & $\begin{array}{c}\text { Foetus } \\
(\mathrm{g})\end{array}$ & $\begin{array}{l}\text { Placenta } \\
(\mathrm{g})\end{array}$ \\
\hline Ovarian end & $\begin{array}{l}1 \\
2 \\
3 \\
4 \\
5 \\
6\end{array}$ & $\begin{array}{l}0.92 \\
0.92 \\
0.98 \\
0.89 \\
0.36 * \\
0.78\end{array}$ & $\begin{array}{l}0.095 \\
0.083 \\
0.098 \\
0.086 \\
0.075 \\
0.082\end{array}$ & $\begin{array}{l}1 \\
2 \\
3 \\
4 \\
5\end{array}$ & $\begin{array}{l}0.86 \\
0.57^{*} \\
0.86 \\
0.95 \\
0.91\end{array}$ & $\begin{array}{l}0.106 \\
0.095 \\
0.101 \\
0.106 \\
0.080\end{array}$ \\
\hline
\end{tabular}

* Runts.

TABLE 4

COMPARISON FOR INBRED AND F1 HYBRID LITTERS OF THE REGRESSION OF THE MEAN WEIGHT OF A LIVE FOETUS ON THE NUMBER OF FOETUSES IN THE LITTER

\begin{tabular}{l|r|r|c|c}
\hline \multicolumn{1}{c|}{ Source of variation } & $d . f$. & $\begin{array}{r}\text { Mean } \\
\text { square } \\
\left(\times 10^{3}\right)\end{array}$ & $F$ & $P$ \\
\hline $\begin{array}{l}\text { Inbred } \\
\quad \text { Regression }\end{array}$ & 1 & 16.23 & 3.27 & $<0.1$ \\
$\quad$ Residual & 27 & 4.96 & & \\
F $_{1}$ hybrid & & & & \\
$\quad$ Regression & 1 & 24.93 & 4.23 & $<0.05$ \\
$\quad$ Residual & 32 & 5.90 & & \\
Comparison & & & & \\
$\quad$ Difference between slopes & 1 & 0.49 & 0.09 & $>0.2$ \\
$\quad$ Distance between lines & 1 & 0.01 & 0.002 & $>0.2$ \\
$\quad$ Combined residual & 59 & 5.47 & & \\
\hline
\end{tabular}

The regression coefficient for inbred litters is $-0.016 \log _{10}$ units, for $F_{1}$ hybrid litters $-0.019 \log _{10}$ units.

Both inbred and $F_{1}$ litters show a negative regression of foetal weight on litter size, though for the inbred litters this does not reach the $P=0.05$ level of significance. Between inbred and $F_{1}$ litters the regression of foetal weight on litter size differs in neither slope nor position: that is, for a given number in the litter, $F_{1}$ young are no heavier at $17 \frac{1}{2}$ days than are inbred young. This contrasts with the situation at birth when $F_{1}$ young are significantly heavier than inbreds (Text-fig. 1).

Placental weight. The mean placental weight for each litter was also calculated, 
omitting placentae attached to dead foetuses. The relation of placental weight to the number of foetuses in the litter is shown in Text-fig. 5 , and the corresponding analysis of variance is given in Table 5.

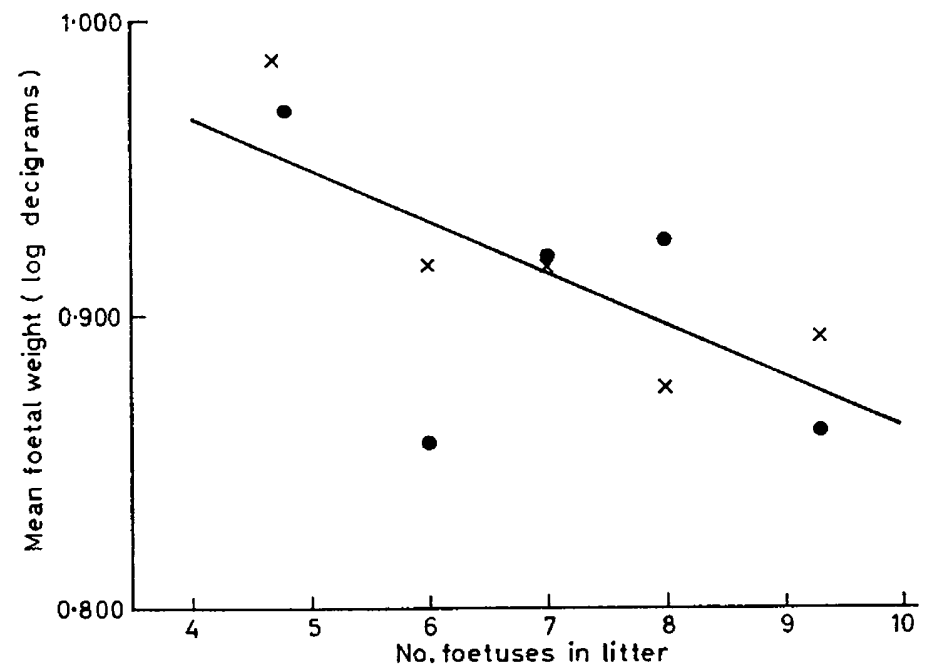

TEXT-FIG. 4. Regression of mean foetal weight on number of foetuses in inbred ( $)$ and $F_{1}$ hybrid $(x)$ litters. The data from Text-figs. 2 and 3 (omitting the two anomalous $F_{1}$ hybrid litters) have been grouped according to number of foetuses in the litter, and the common regression line drawn. In some instances litter size classes have been combined to ensure that each point is based on at least three litters.

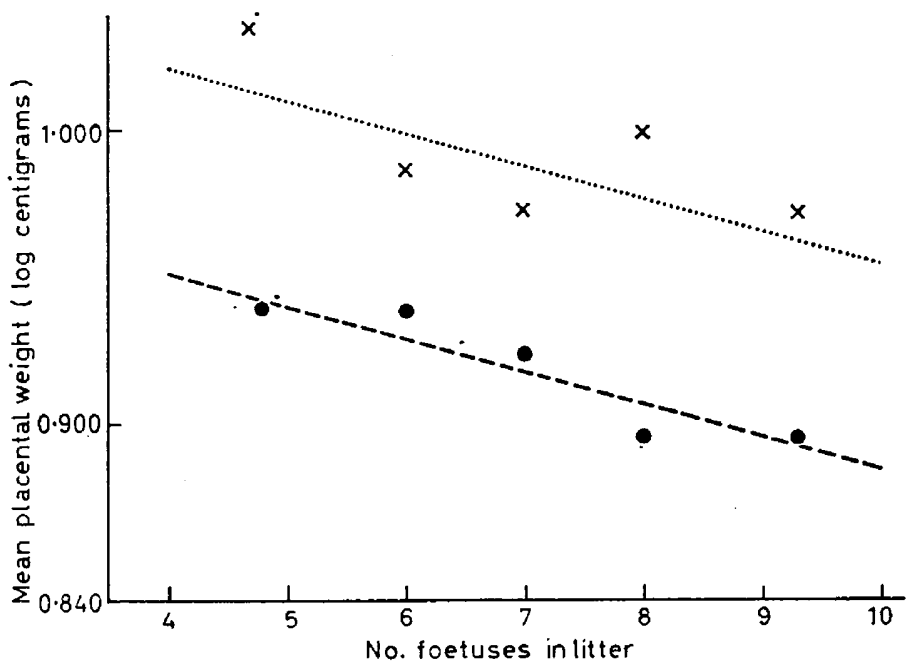

TExT-FIG. 5. Regression of mean placental weight on number of foetuses in inbred $(O)$ and $F_{1}$ hybrid $(x)$ litters. The data are grouped as in Text-fig. 4 . Two regression lines have been fitted, using a common slope.

Both inbred and $F_{1}$ litters show a significant negative regression of placental weight on litter size. The slope of this regression is similar in inbred and $F_{1}$ litters, but there is a highly significant difference in position of the two regression lines. For a given litter size, placentae in $F_{1}$ litters are heavier than those in inbred litters by $0.07 \log$ units, i.e. by $17 \cdot 5 \%$. 
Placental weight is markedly less variable from litter to litter than is foetal weight. Comparison of the residual mean squares in Tables 4 and 5 shows this to be true for both inbred $\left(\mathrm{F}_{(27,27)}=3.91, P<0.001\right)$ and $\mathrm{F}_{1}$ hybrid $\left(\mathrm{F}_{(32,32)}=\right.$ $4.28, P<0.001)$ litters. Neither foetal nor placental weight differs significantly in variability between inbred and $F_{1}$ litters.

\section{Local and systemic effects}

Mean birth weight, and foetal and placental weight at $17 \frac{1}{2}$ days' gestation, are all lower for individuals in large litters than for those in small litters. The effects of other foetuses on foetal and placental growth may be confined to a single uterine horn (local effects) or may operate to the same extent whether the competitors are in the same or in the opposite horn of the uterus (systemic effects). We may distinguish between local and systemic effects by the method of Healy et al. (1960).

\section{TABLE 5}

COMPARISON FOR INBRED AND F1 HYBRID LITTERS OF THE REGRESSION OF MEAN PLACENTAL WEIGHT ON THE NUMBER OF FOETUSES IN THE LITTER

\begin{tabular}{|c|c|c|c|c|}
\hline Source of variation & $d . f$. & $\begin{array}{c}\text { Mean } \\
\text { square } \\
\left(\times 10^{3}\right)\end{array}$ & $F$ & $P$ \\
\hline $\begin{array}{l}\text { Inbred } \\
\text { Regression } \\
\text { Residual }\end{array}$ & $\begin{array}{r}1 \\
27\end{array}$ & $\begin{array}{l}8.03 \\
1.27\end{array}$ & 6.33 & $<0.05$ \\
\hline $\begin{array}{c}F_{1} \text { hybrid } \\
\text { Regression } \\
\text { Residual }\end{array}$ & $\begin{array}{r}1 \\
32\end{array}$ & $\begin{array}{l}8.87 \\
1.38\end{array}$ & 6.42 & $<0.05$ \\
\hline $\begin{array}{l}\text { Comparison } \\
\text { Difference between slopes } \\
\text { Distance between lines } \\
\text { Combined residual }\end{array}$ & $\begin{array}{r}1 \\
1 \\
59\end{array}$ & $\begin{array}{r}0.01 \\
74.33 \\
1.33\end{array}$ & $\begin{array}{r}0.00 \\
55.90\end{array}$ & $\begin{array}{l}>0.2 \\
\ll 0.001\end{array}$ \\
\hline
\end{tabular}

The regression coefficient for inbred litters is $-0.011 \log _{10}$ units, for $F_{1}$ hybrid litters $-0 \cdot 012 \log 10$ units.

If we assume that the effect of foetal number on log foetal or placental weight is linear, then if $y_{\mathrm{L}}$ is the mean log foetal or placental weight in the left horn of a uterus, and $x_{\mathrm{L}}, x_{\mathrm{R}}$ are the numbers of foetuses in the left and right horns, the simplest model gives

$$
E\left(y_{\mathrm{L}}\right)=\mu_{\mathrm{L}}+\beta_{1} x_{\mathrm{L}}+\beta_{\mathrm{s}}\left(x_{\mathrm{L}}+x_{\mathrm{R}}\right),
$$

where $E$ indicates an expected value and $\beta_{1}$ and $\beta_{\mathrm{s}}$ measure the local and systemic effects, respectively. The right horn yields a similar equation; adding and subtracting these two equations, we have

$$
\begin{aligned}
& E\left(y_{\mathrm{L}}+y_{\mathrm{R}}\right)=\mu_{\mathrm{L}}+\mu_{\mathrm{R}}+\left(\beta_{1}+2 \beta_{\mathrm{S}}\right)\left(x_{\mathrm{L}}+x_{\mathrm{R}}\right) \\
& E\left(y_{\mathrm{L}}-y_{\mathrm{R}}\right)=\mu_{\mathrm{L}}-\mu_{\mathrm{R}}+\beta_{1}\left(x_{\mathrm{L}}-x_{\mathrm{R}}\right)
\end{aligned}
$$

We now form the sums and differences, for the two horns of each uterus, of mean log foetal or placental weight and of foetal number, and calculate the 
simple regressions of sums on sums and of differences on differences. This gives regression coefficients $b_{\mathrm{S}}$ for the sums and $b_{\mathbf{D}}$ for the differences, from which we can obtain estimates $b_{1}$ and $b_{8}$ of $\beta_{1}$ and $\beta_{8}$ as follows:

$$
\begin{aligned}
& b_{1}=b_{\mathrm{D}} \\
& b_{\mathrm{s}}=\frac{1}{2}\left(b_{\mathrm{S}}-b_{\mathrm{D}}\right)
\end{aligned}
$$

Since $b_{\mathrm{S}}$ and $b_{\mathrm{D}}$ are not correlated,

and

$$
\begin{aligned}
& \operatorname{var}\left(b_{\mathrm{B}}\right)=\frac{1}{4}\left\{\operatorname{var}\left(b_{\mathrm{S}}\right)+\operatorname{var}\left(b_{\mathrm{D}}\right)\right\}, \\
& \operatorname{var}\left(b_{1}\right)=\operatorname{var}\left(b_{\mathbf{D}}\right)
\end{aligned}
$$

Table 6 lists local and systemic effects of number on foetal and on placental weight, in inbred and in $F_{1}$ hybrid litters. No differences appear between inbred and $F_{1}$ material, so in each case a combined value has been calculated.

\begin{tabular}{|c|c|c|c|}
\hline & & Local effect $\left(b_{l}\right)$ & Systemic effect $\left(b_{s}\right)$ \\
\hline \multirow[t]{2}{*}{ Foetal weight } & $\begin{array}{l}\text { Inbred } \\
\text { F }_{1} \text { hybrid }\end{array}$ & $\begin{array}{l}-382 \pm 380 \\
-453 \pm 231\end{array}$ & $\begin{array}{r}-816 \pm 849 \\
-1617 \pm 926\end{array}$ \\
\hline & Combined & $-434 \pm 197 *$ & $-1181 \pm 627$ \\
\hline \multirow[t]{2}{*}{ Placental weight } & $\begin{array}{l}\text { Inbred } \\
\mathrm{F}_{1} \text { hybrid }\end{array}$ & $\begin{array}{l}+240 \pm 403 \\
+154 \pm 341\end{array}$ & $\begin{array}{r}-950 \pm 456^{*} \\
-1067 \pm 446^{*}\end{array}$ \\
\hline & Combined & $+190 \pm 260$ & $-1010 \pm 319 * *$ \\
\hline \multirow{2}{*}{$\begin{array}{l}\text { Foetal weight (effect of } \\
\text { placental weight } \\
\text { excluded) }\end{array}$} & $\begin{array}{l}\text { Inbred } \\
\text { F }_{1} \text { hybrid }\end{array}$ & $\begin{array}{l}-386 \pm 370 \\
-504 \pm 205 *\end{array}$ & $\begin{array}{l}-1365 \pm 875 \\
-1323 \pm 1009\end{array}$ \\
\hline & Combined & $-476 \pm 179 *$ & $-1347 \pm 661^{*}$ \\
\hline
\end{tabular}

TABLE 6

LOCAL AND SYSTEMIC EFFEGTS OF FOETAL NUMBER ON FOETAL AND PLACENTAL WEIGHT IN INBRED AND F1 HYBRID LITTERS

$b_{1}$ and $b_{s}$ are in $10^{5} \times \log _{10}$ units.

$* P<0.05 ; * * P<0.01$.

On foetal weight, both inbreds and $F_{1}$ hybrids show a non-significant negative local effect of number; the combined value for local effect is significant. Both groups also show a non-significant negative systemic effect on foetal weight; the combined value is more than twice as great as the corresponding local effect, but does not reach the $5 \%$ level of significance $(0 \cdot 1>P>0.05)$ as the variance is very high. On placental weight, the local effect in both groups is positive, small and non-significant; the systemic effect is negative, large and significant.

Since (as we shall see below) there is an association between foetal and placental weight, we may enquire whether the sub-significant systemic effect of number on foetal weight disappears when allowance for placental weight is made, or whether the effect is exerted independently of placental weight. Partial regressions of sums on sums and differences on differences were therefore calculated, taking foetal weight as the dependent variable, and placental weight and number of foetuses as the two independent variables. From the partial regression coefficients, local and systemic effects of number on foetal weight, with placental weight excluded, were worked out, and are shown in 
Table 6. It is clear that both the local and systemic effects of number on foetal weight operate independent of placental weight. The combined value for the systemic effect of number on foetal weight just reaches the $5 \%$ level of significance.

Thus each surviving implantation retards, by about $1 \%$, the growth of of every other foetus in the same uterine horn, and may exert an additional systemic effect, amounting to a further retardation of about $3 \%$, on the growth of its fellows whether in the same or opposite horn. By contrast, the effect of the number in the litter on placental growth is entirely systemic: each surviving implantation has a retarding effect of nearly $3 \%$ on the growth of all ather placentae, irrespective of which horn they are in. A litter of ten distributed eight in one uterine horn, two in the other, would therefore be expected to have smaller foetuses in the more crowded horn, but the same sized placentae in each.

\section{Relation of foetal to placental weight, between females and between uterine horns}

Are heavier foetuses associated with heavier placentae? This question may be investigated at three levels:

(1) Between females.

(2) Between the two uterine horns of each female.

(3) Between the foetuses in each uterine horn.

When different litters are compared, mean foetal weight is negatively correlated with the number of foetuses in the litter (Table 4). Similarly, when the two uterine horns of the same female are compared, mean foetal weight is negatively correlated with the number of foetuses in the horn (Table 6, local effect). In considering the effect of placental weight on foetal weight between females and between uterine horns, it is therefore necessary in each case to calculate the partial regression of foetal weight on number of foetuses and placental weight. The appropriate partial regression coefficients are listed in Table 7.

In no instance do the coefficients in the inbred and $F_{1}$ hybrid groups differ significantly from one another: combined coefficients have therefore been calculated. As expected, after allowing for the effects of placental weight there is a significant negative regression of foetal weight on number of foetuses, both among females and between uterine horns. When the effect of number of foetuses is allowed for, the relation of foetal weight to placental weight in different females is negative and not significant; but between the two horns of a single female, the regression is positive and highly significant. (Differences between horns in mean placental weight will arise at least in part as a consequence of variation in placental weight within horns; a more complex statistical analysis would be needed to decide whether the horns differed significantly in their capacity to support placental growth.)

In other words within any one female, when allowance for foetal number has been made, the uterine horn containing the heavier placentae is likely also to have the heavier foetuses; but this is not true when different females are compared. 


\section{Foetal and placental weight within uterine horns}

Before investigating the question whether the heavier foetuses within a uterine horn are associated with the heavier placentae, we need to know how the weight of a foetus or a placenta is affected by its position in the uterine horn. Since the order of implantations within each uterine horn was recorded, but not their position in absolute terms, it has been assumed for the present purposes that implantations are spaced evenly down the length of the horn.

In analysing variation of foetal and placental weight within uterine horns, the two horns containing runt foetuses (see p. 84) have been omitted. The inclusion of runt observations, falling outside the normal range of variation, has little effect on mean values for the litter or horn, but seriously inflates estimates of variation within horns. An additional $F_{1}$ horn has been omitted, since the order of the foetuses was not recorded.

\section{TABLE 7}

PARTIAL REGRESSION COEFFICIENTS IN LOG10 UNITS OF FOETAL WEIGHT ON PLACENTAL WEIGHT AND ON NUMBER OF FOETUSES, BETWEEN FEMALES AND BETWEEN UTERINE HORNS OF THE SAME FEMALE

\begin{tabular}{|c|c|c|c|}
\hline & & \multicolumn{2}{|c|}{ Regression of foetal wt on: } \\
\hline & & $\begin{array}{l}\text { Placental wt } \\
\text { (No. excluded) }\end{array}$ & $\begin{array}{c}\text { No. foetuses } \\
\text { (placental wt excluded) }\end{array}$ \\
\hline Between females & $\begin{array}{l}\text { Inbred } \\
F_{1} \\
\text { Combined }\end{array}$ & $\begin{array}{l}-0.600 \pm 0.369 \\
+0.197 \pm 0.370 \\
-0.202 \pm 0.261\end{array}$ & $\begin{array}{l}-0.0221 \pm 0.0093^{*} \\
-0.0171 \pm 0.0104 \\
-0.0199 \pm 0.0069^{* *}\end{array}$ \\
\hline $\begin{array}{l}\text { Between uterine horns } \\
\text { of a single female }\end{array}$ & $\begin{array}{l}\text { Inbred } \\
F_{1} \\
\text { Combined }\end{array}$ & $\begin{array}{l}+0.332 \pm 0.176 \\
+0.334 \pm 0.106^{* *} \\
+0.333 \pm 0.091^{* * *}\end{array}$ & $\begin{array}{l}-0.00386 \pm 0.00370 \\
-0.00504 \pm 0.00205 * \\
-0.00476 \pm 0.00179 *\end{array}$ \\
\hline
\end{tabular}

${ }^{*} P<0.05 ; * * P<0 \cdot 01 ; * * P<0.001$.

Hashima (1956) reported that the foetus at the extreme ovarian end of the uterine horn weighed less on average than its neighbour. Healy et al. (1960) found that this restriction of growth of the ovarian foetus was only significant in the more crowded uterine horns ( 8 to 13 foetuses). In the present material, only two harns contained seven foetuses; none contained more. It is, therefore, not surprising that, in the thirty-five inbred and forty-one $F_{1}$ horns containing three or more foetuses, in which both the ovarian foetus and its neighbour were alive at $17 \frac{1}{2}$ days, no tendency was found for the ovarian foetus or its placenta to weigh less than its neighbour. Horns containing five or six foetuses showed no more sign of any such effect than those containing three or four foetuses.

To gain an impression of the way in which foetal and placental weights are distributed down the length of the uterine horn, each horn may be arbitrarily divided into six equal segments (I to VI), and weighted means calculated for each segment separately. For horns containing three foetuses, the mean value for the first foetus or placenta will contribute half its weight (in the statistical sense) to segment I and half to segment II; the second foetus or placenta will in 
the same way contribute to segments III and IV, and the third to segments V and VI. Similarly, for horns containing five foetuses, the mean value for the first will contribute $5 / 6$ of its statistical weight to segment $I$ and $1 / 6$ to segment II, the second will contribute $2 / 3$ to segment II and $1 / 3$ to segment III, and so on.

The weighted mean values, converted to milligrams and adjusted to allow for the slightly greater mean number in $F_{1}$ horns, are shown in Table 8 for all uterine horns containing more than one foetus. As reported by McLaren \& Michie (1959a), the foetuses in the top (ovarian) half of the horn tend to be heavier than those in the lower (cervical) half. This is so for both inbred and $F_{1}$ foetuses; it is also so for placentae. On the other hand there is little or no sign of any increase in foetal weight as the cervical end of the horn is approached (McLaren \& Michie 1959a).

\section{TABLE 8}

EFFECT OF POSITION IN THE UTERINE HORN ON FOETAL AND PLACENTAL WEIGHTS (FIFTY-FOUR INBRED AND SIXTY-FIVE F1 UTERINE HORNS)

\begin{tabular}{|c|c|c|c|c|c|c|c|}
\hline & & \multicolumn{5}{|c|}{$\begin{array}{c}\text { Ovarian } \\
\text { end }\end{array}$} & \multirow{2}{*}{$\begin{array}{c}\begin{array}{c}\text { Cervical } \\
\text { end }\end{array} \\
\qquad \mathrm{VI}\end{array}$} \\
\hline & & \multicolumn{4}{|c|}{ Arbitrary segment of uterine horn } & $\stackrel{\text { horn }}{\mathrm{V}}$ & \\
\hline $\begin{array}{l}\text { Foetal wt } \\
\text { (mg) }\end{array}$ & $\begin{array}{l}\text { Inbred } \\
\mathbf{F}_{1}\end{array}$ & $\begin{array}{l}824 \\
804\end{array}$ & $\begin{array}{l}820 \\
805\end{array}$ & $\begin{array}{l}815 \\
818\end{array}$ & $\begin{array}{l}794 \\
798\end{array}$ & $\begin{array}{l}794 \\
774\end{array}$ & $\begin{array}{l}783 \\
782\end{array}$ \\
\hline $\begin{array}{l}\text { Placental wt } \\
\text { (mg) }\end{array}$ & $\begin{array}{l}\text { Inbred } \\
\mathbf{F}_{1}\end{array}$ & $\begin{array}{l}83 \cdot 2 \\
98 \cdot 9\end{array}$ & $\begin{array}{l}81 \cdot 8 \\
99 \cdot 3\end{array}$ & $\begin{array}{l}81 \cdot 7 \\
96 \cdot 8\end{array}$ & $\begin{array}{l}80 \cdot 0 \\
93 \cdot 5\end{array}$ & $\begin{array}{l}80 \cdot 2 \\
92 \cdot 9\end{array}$ & $\begin{array}{l}80 \cdot 9 \\
93.5\end{array}$ \\
\hline
\end{tabular}

The $F_{1}$ values have been adjusted to allow for a small difference between $F_{1} s$ and inbreds in the mean number of foetuses in the horn.

To assess the significance of the effect of position in the horn, linear regressions of foetal and placental weight on position in the horn have been calculated. For this purpose the arbitrary division of the horn into six segments has been abandoned; instead, a horn containing $n$ foetuses has been regarded as consisting of $n$ segments, and each foetus has been located at the mid-point of the appropriate segment. Thus, if the horn is taken to be of unit length, two foetuses would be assigned positions 0.25 and 0.75 of the distance along the horn; five foetuses would be assigned positions $0.9,0 \cdot 7,0 \cdot 5,0.3$ and $0 \cdot 1$, and so on.

Since the two uterine horns of a female resemble one another closely in respect of the mean weight both of the foetuses and of the placentae which they contain, it is likely that regressions of foetal or placental weight on position in the horn, or regressions of foetal weight on placental weight, would also show correlations between horns. The significance of the results would therefore be over-estimated if the two uterine horns of an individual were to be treated as independent observations. For this reason all computations in this section have 
been done separately for left and right horns, and no attempt made to calculate a joint significance. No significant departures from linearity were observed.

Table 9 shows that, in every instance, the regression of foetal or placental weight on position in the horn was positive: that is, the nearer to the cervical end of the horn a foetus or placenta was situated, the more in general it weighed. The effect was more marked in the right horn than in the left. For placentae in inbred females, the regression was not statistically significant.

TABLE 9

REgRESSION OF FOETAL AND PLACENTAL WEIGHTS (IN LOG10 UNITS) ON POSITION IN THE UTERINE HORN

\begin{tabular}{l|l|l|l}
\hline & & \multicolumn{2}{|c}{ Regression coefficient \pm s.e. } \\
\cline { 2 - 3 } & & Left horn & Right horn \\
\hline Foetal wt & Inbred & $+0.0224 \pm 0.0144$ & $+0.0295 \pm 0.0134^{*}$ \\
& $\mathrm{~F}_{1}$ & $+0.0063 \pm 0.0104$ & $+0.0415 \pm 0.0124^{* *}$ \\
\hline Placental wt & Inbred & $+0.0150 \pm 0.0172$ & $+0.0201 \pm 0.0179$ \\
& $\mathrm{~F}_{1}$ & $+0.0358 \pm 0.0113^{* *}$ & $+0.0606 \pm 0.0182^{* *}$ \\
\hline
\end{tabular}

The length of the horn is taken as one unit.

$* P<0.05 ; * * P<0.01$.

TABLE 10

PARTIAL REGRESSION COEFFICENTS (IN LOG 10 UNITS), SHOWING EFFECT OF PLACENTAL WEIGHT AND POSITION IN HORN ON FOETAL WEIGHT

\begin{tabular}{l|c|c|c|c}
\hline & \multicolumn{2}{|c|}{ Inbred } & \multicolumn{2}{c}{$F_{1}$ hybrid } \\
\cline { 2 - 5 } & Left & Right & Left & Right \\
\hline Placental wt (allowing for & $+0.2516^{*}$ & $+0.3163^{* * *}$ & $+0.2937^{* *}$ & $+0.1993^{* *}$ \\
position in horn) & \pm 0.1075 & \pm 0.0711 & \pm 0.1052 & \pm 0.0735 \\
Position in horn (allowing & +0.0187 & +0.0232 & -0.0043 & +0.0181 \\
for placental wt) & \pm 0.0140 & \pm 0.0120 & \pm 0.0129 & \pm 0.0112 \\
\hline
\end{tabular}

$* P<0.05 ; * * P<0.01 ; * * * P<0.001$.

The last problem concerns the relative dependence of foetal weight on placental weight and on position in the uterine horn. Are the heavier foetuses in a horn associated with the heavier placentae, even when allowance is made for the effect of position in the horn? And conversely, does position in the horn affect foetal weight directly, or only via placental weight? To investigate these questions, partial regressions of foetal weight on placental weight and on position in the horn were calculated. Again, left horns and right horns were treated separately. The results are shown in Table 10.

Foetal weight shows a strong dependence on placental weight in all groups, even when allowance for position in the horn is made. On the other hand, when placental weight is allowed for, no significant effect of position in the horn on foetal weight remains. It seems, then, as though foetal growth is influenced by placental growth, which in turn depends upon position in the horn. 


\section{DISCUSSION}

\section{Foetal and placental heterosis}

The finding that for a given litter size $F_{1}$ hybrid young are heavier at birth than are inbred young born to females of the same strain is not unexpected. Vetulani (1930) crossed strains of mice differing in mean birth weight, and found that the birth weight of the $F_{1}$ hybrids was intermediate between the two parental strains: but the strains were not highly inbred. Gates, Doyle \& Noyes (1961) studied a strain combination in which the $\mathrm{F}_{1}$ young near term were $20 \%$ heavier than the corresponding inbred young. Even before implantation their $\mathrm{F}_{1}$ blastocysts contained more cells than did inbred blastocysts of the same age. McCarthy (1963) has found heterosis in birth weight on crossing six inbred strains of mice.

Birth weight is an unsatisfactory index of prenatal growth unless the gestation period is known also. A decrease in birth weight may reflect a shortened gestation period rather than reduced growth; if gestation is prolonged, birth weight will increase, while if prenatal growth is increased the gestation period may well be reduced. In the present strain combination (C57BL 9 , C57BL or $\left.\mathrm{C}_{3} \mathrm{H}^{3}\right) \mathrm{F}_{1}$ hybrid litters have a shorter gestation period, by nearly half a day, than inbred litters containing the same number of young (McLaren \& Michie, 1963). The superiority of the $F_{1}$ young in birth weight (about $6 \%$ ) is therefore an underestimate of foetal heterosis: if females pregnant with $F_{1}$ and inbred litters were killed at the expected time of birth of the $F_{1}$ young (say $18 \frac{3}{4}$ days' gestation for a litter of average size), the difference in mean weight between inbred and $F_{1}$ young should exceed $6 \%$.

Yet at $17 \frac{1}{2}$ days' gestation, scarcely more than $24 \mathrm{hr}$ earlier, the difference in weight between inbred and $F_{1}$ was for this strain combination negligible. The final $24 \mathrm{hr}$ of pregnancy is a period of intensive growth, during which the foetus increases in weight by more than $50 \%$ (compare the foetal weights in Table 8 with the birth weights given on p. 82); and it is chiefly in this period that the greater growth potential of the $F_{1}$ young is realized. At the start of a phase of rapid foetal growth, small differences in developmental age will lead to large differences in foetal weight: the greater variation among females in foetal than in placental mean weight (p. 87) is therefore to be expected, since the phase of rapid placental growth occurs several days earlier.

The extent of placental heterosis is very striking, since at $17 \frac{1}{2}$ days the placentae in $F_{1}$ litters are nearly $20 \%$ heavier than those in inbred litters. The chorio-allantoic placenta is a compound structure, part maternal, part foetal: the maternal component is presumably not affected by heterosis, but by this stage of pregnancy it forms only a very small part of the total placenta (Huggett \& Pritchard, 1944).

The phenomenon is not restricted to the strain combination used in the present work. McCarthy (1963) examined four different strain combinations, and found foetal heterosis in all four, and placental heterosis in three out of four. The fact that the fourth combination showed foetal heterosis without placental heterosis suggests that the greater growth potential of the $F_{1}$ foetus is, or at any rate can be, intrinsic to the foetus itself, and is not a consequence of the increased size of the $F_{1}$ placenta. 


\section{The haemodynamic theory}

The larger the litter, the smaller each member tends to be (Text-figs. $I$ and 4). This effect, which can be seen in the human species and many others, has usually been attributed to prenatal competition among the young for a limited supply of nutrients in the maternal circulation. In animals such as sheep, which are born at a relatively advanced stage of development, prenatal competition for nutrients undoubtedly plays a part. But in mice, there is direct evidence that foetal weight is unaffected by the nutritional state of the mother (Healy et al., 1960); and in addition there are several aspects of the pattern of foetal growth which cannot be accounted for on any theory based on competition for a limited pool of nutrients (McLaren \& Michie, 1960b).

More consistent with the experimental evidence is the haemodynamic theory of foetal growth. Eckstein \& McKeown (1955) and Eckstein, McKeown \& Record (1955) made an extensive study of foetal and placental growth in guinea-pigs, and found that in large litters the effect which litter-mates exerted on growth was greater if they were in the same than if they were in the opposite uterine horn. This local effect, to use the terminology introduced earlier, could, they suggested, be due to limitation of the blood supply to the uterus. Healy et al. (1960) and McLaren \& Michie (1960b) extended the haemodynamic theory on the basis of their observations on mice. These included (a) the existence of local as well as systemic effects on foetal growth, (b) the influence which foetuses dying in mid-pregnancy exerted on the growth of the survivors, (c) the effect of position in the uterine horn, and (d) the stunting of foetal growth assaciated with placental fusion. In particular, they postulated that the quantity of nutrients available for foetal growth depends both on the pressure at which maternal blood reaches the placenta, and also on placental size, and that placental size is in turn dependent on blood pressure.

Because of the low resistance which the capillary network of the placenta provides, maternal blood pressure will tend to be low when the number of placentae is high, unless the increase in total blood volume during pregnancy is adequately geared to the number of young in the litter. Rodbard \& Katz (1944), working on dogs, reported a reduction in maternal blood pressure in late pregnancy; as might be expected, the reduction was larger in big litters. A similar effect in mice would explain, on the haemodynamic theory, the effect of foetal number on foetal growth. If the reduction in blood pressure was the same in both uterine arteries irrespective of the distribution of implantations, the effect on growth would operate systematically; otherwise a local effect would be expected (see below).

\section{Effect of position in the uterine horn}

A strong piece of circumstantial evidence in favour of the haemodynamic theory was the tendency, observed by McLaren \& Michie (1959a) in mice, and by Waldorf, Foote, Self, Chapman \& Casida (1957) in pigs, for foetal weight to decrease from the ovarian end of the horn towards the middle, with a slight increase again near the cervical end. Each horn of the uterus is supplied anteriorly and posteriorly by branches from the aorta, which usually (though not always) join in the uterine mesentery to form a loop vessel. Offshoots lead 
to the ovary and to the horn itself, supplying blood, in the pregnant uterus, to each placenta. In such a system of side-branches from a loop vessel fed at both ends, a pressure gradient will be encountered from each end towards the middle. This pressure gradient was invoked to explain the observed gradient in foetal weight. The present study supports the earlier one in that foetal weight is again lower in the cervical than in the ovarian half of each uterine horn, but conflicts with it in that foetal weight shows no tendency to increase again as the cervical end is approached. This difference (like the failure to detect any retardation of growth of the foetus at the extreme ovarian end of the horn) may be associated with the fact that the mean number of implantations per horn in the present study was only 3.9 , with a maximum of 7 , as compared with a mean of 9.7 and a maximum of 16 for the superovulated material analysed previously. A tendency for foetal weight to decrease from the ovarian to the cervical end of the uterine horn was also reported by Rosahn \& Greene (1936) in rabbits.

Placental weight, in the present study as well as in the earlier reports of Rosahn \& Greene (1936) and Waldorf et al. (1957), showed the same relation as foetal weight to position in the uterine horn. The present data also confirm the finding of Waldorf et al. (1957) that the decline in foetal weight is not an independent effect, but is associated with the decline in placental weight. So if a haemodynamic interpretation is to be sought, one must postulate that the variation in blood pressure down the length of the horn does not affect foetal growth directly, but does affect placental growth, and that the size which the placenta attains is a determining factor in the growth of the foetus.

\section{Local and systemic effects}

If the effect of position in the horn on placental growth is attributed to haemodynamic factors (i.e. to a gradient of blood pressure along the horn), it follows that the placenta is a sensitive indicator of blood pressure levels, more sensitive perhaps than the foetus (which shows no independent effect of position in the horn). Yet in neither inbred mice nor in $\mathrm{F}_{1}$ hybrids (Table 6) do we find any indication of any local inhibitory effect of numbers on placental growth. The more extensive study of McCarthy (1963) confirms this point: the local effect of numbers on placental weight consistently takes a small positive value. On the other hand, both in the present work and in that of McCarthy (1963), there is a large and highly significant systemic effect of numbers on placental growth. This suggests (i) that the more young a pregnant female is carrying, the lower is the pressure at which maternal blood is supplied to each placenta, and (ii) that this pressure is independent of the distribution of implantations between uterine horns, presumably because the rate of blood flow through each uterine artery varies with the number of placentae in the corresponding horn. If the blood flow were divided equally between the two uterine arteries, the pressure at which maternal blood reached each implantation site would be inversely proportional to the number of placentae in the horn, and a negative local effect would be observed.

The small positive local effect of numbers on placental growth is not significantly different from zero either in the present study or in that of McCarthy 
(1963). But since in both it is consistently positive in every strain combination tested, the effect is probably real. What could cause placentae to grow larger in more crowded horns is by no means obvious: at any rate the explanation is unlikely to be haemodynamic.

From the absence of a negative local effect on placental growth we have argued that the blood pressure in each uterine artery cannot depend on the distribution of implantations between uterine horns. But if the haemodynamic basis for a local effect does not exist for placental growth, it cannot exist for foetal growth either. We must therefore seek some other explanation of the inhibitory effect of local crowding on foetal growth. The most probable would seem to be a mechanical one. The wall of the uterine horn is semi-elastic, its degree of stretching depends on how many foetuses it contains, and the growth

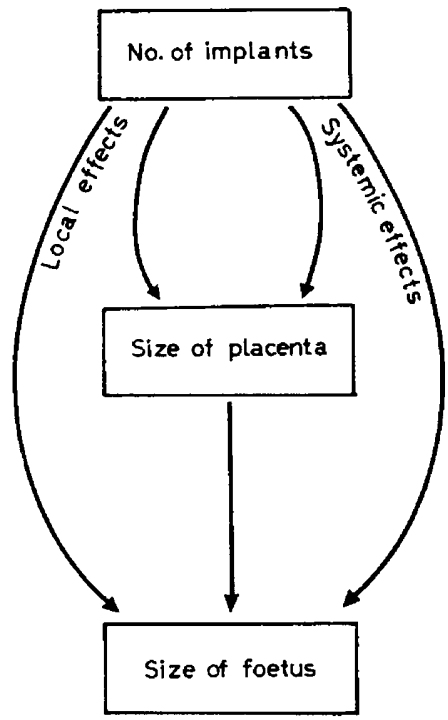

(a)

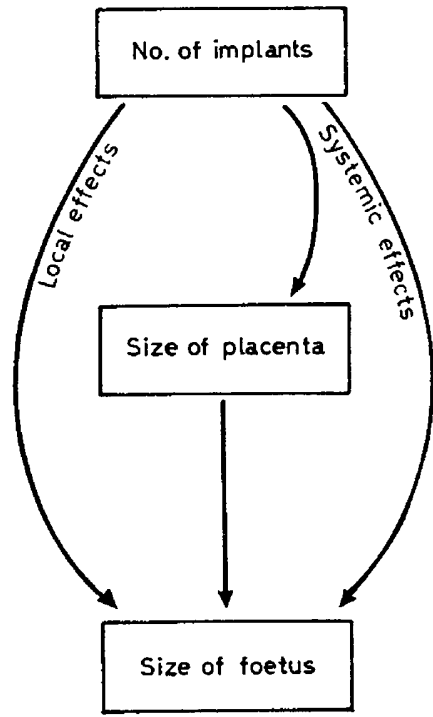

(b)

Text-Fig. 6. Pathways by which foetal number appears to influence foetal growth, (a) in the analysis by Eckstein et al. (1955) of foetal growth in guinea-pigs, (b) in the present study.

of these foetuses may well be sensitive to the extent of the mechanical pressure that the uterine wall exerts on them. On the other hand there is no reason to doubt the haemodynamic basis of any systemic effect of number on foetal growth, whether exerted directly or via the placenta.

In guinea-pigs the situation appears to be different, since Eckstein \& McKeown (1955) and Eckstein et al. (1955) report that the number of implants exerts local as well as systemic effects on foetal and on placental growth. Although foetal weight was positively correlated with placental weight, neither the local nor the systemic effect of number of foetuses on foetal growth could be wholly explained by an effect on placental size. A formal representation of such a situation is given in Text-fig. 6(a), which is adapted from Healy et al. (1960). For comparison, Text-fig. 6(b) summarizes the situation revealed in the present study. 
In pigs, although Waldorf et al. (1957) do not distinguish between local and systemic effects, they report that the strong influence of number per horn on foetal weight is exerted very largely via placental weight.

\section{Relation of foetal to placental growth}

A correlation between foetal and placental size has been reported in many species, including rabbits (Hammond, 1935; Rosahn \& Greene, 1936), guineapigs (Eckstein et al., 1955), pigs (Waldorf et al., 1957) and man (Adair \& Thelander, 1925). Such a relation is confirmed in the present work. Within a uterine horn, the heavier foetuses were associated with the heavier placentae. Placental growth varied along the length of the uterine horn, and this variation was reflected in foetal growth; and even allowing for position in the horn, there was a further, independent association of foetal size with placental size. Comparing the two horns of the uterus, the horn with the heavier placentae also tended to contain the heavier foetuses, even when due allowance for the number of implantations in each had been made. Unexpectedly, no association between foetal and placental size was observed when different females were compared. However, this could well have been due to small differences in stage of development among the different pregnancies: since between 17 and 18 days' gestation, while the foetus is increasing very rapidly in size, the placenta tends to lose weight (McLaren, unpublished; a decrease in placental weight towards the end of pregnancy has also been reported by Flexner \& Pohl (1941) in the rat). Hence the physiologically more advanced pregnancies would tend to have larger foetuses and smaller placentae, and a positive association between foetal and placental growth might be obscured.

Foetal growth and placental growth do not always go hand in hand. For instance, Sugiyama (1961) observed that placental weight may increase with parity while foetal weight remains constant. In such cases it may be that the increase in weight of the placenta is not accompanied by any corresponding increase in its capacity to transfer nutrients to the foetus.

Conversely, a positive association does not necessarily indicate a direct causal relationship. One possible basis for a positive correlation between foetal and placental weight in outbred material might be genetic variation in growth rate among conceptuses. A genetic constitution which favoured rapid growth in the foetus might well do so in the foetal part of the placenta also (such a situation is exemplified by our earlier comparison between inbred and hybrid conceptuses). As Barcroft (1946) has argued, the fact that the size of the foetus is often proportional to the extent of its membranes 'does not necessarily mean that the size of the foetus is conditioned by the extent of its membranes or of any part of them. If the membranes be regarded as part of the foetus, there is every likelihood that the size of the foetus and the extent of the membrane would usually go hand in hand'.

In the present study, use of inbred material has eliminated genetic heterogeneity within litters. The positive association between foetal and placental weight cannot therefore be genetic in origin. Nonetheless, Barcroft's argument remains. The pressure at which maternal blood arrives at the placenta, and other factors too, may affect both placental growth and foetal growth, 
independently but in a largely parallel way. Yet the finding that position in the horn affects placental growth primarily and foetal growth only via placental growth, strongly suggests that the size of the placenta in itself affects the amount of nutrients that the foetus can take up from the maternal blood, and hence influences foetal growth. In the limiting case, where the placenta is very small, this must be so.

\section{REFERENGES}

Adatr, F. L. \& Thelander, H. (1925) A study of the weight and dimensions of the human placenta in its relation to the weight of the newborn infant. Amer. 7. Obstet. Gynec. 10, 172.

Barcroft, J. (1946) Researches on prenatal life, vol. 1. Blackwell Scientific Publications, Oxford.

Brumby, P. J. (1960) The influence of the maternal environment on growth in mice. Heredity, 14, 1.

Dixon, W. J. (1953) Processing data for outliers. Biometrics, 9, 74.

Eckstein, P. \& McKeown, T. (1955) Effect of transection of one horn of the guinea-pig's uterus on foetal growth in the other horn. F. Endocrin. 12, 97.

Eckstein, P., McKeown, T. \& REcoRd, R. G. (1955) Variation in placental weight according to litter size in the guinea-pig. F. Endocrin. 12, 108.

Flexner, L. B. \& Pohr, H. A. (1941) The transfer of radioactive sodium across the placenta of the white rat. f. cell. comp. Physiol. 18, 49.

Gates, A. H., Doyle, L. L. \& Noyes, R. W. (1961) A physiological basis for heterosis in hybrid mouse fetuses (Abstr.) Amer. Zool. 1, 449.

Gates, W. H. (1924) Litter size, birth weight and early growth rate of mice (Mus musculus). Anat. Rec. 29, 183.

GrüneberG, H. (1952) The genetics of the mouse, 2nd edn. Martinus Nijhoff, The Hague.

Haldane, J. B. S. (1945) The use of $\chi^{2}$ as a test of homogeneity in a $(n \times 2)$-fold table when expectations are small. Biometrika, 33, 234.

Hammond, J. (1935) The changes in the reproductive organs of the rabbit during pregnancy. Trans. Dynam. Developm. 10, 93.

Hashima, H. (1956) Studies on the prenatal growth of the mouse with special reference to the site of implantation of the embryo. Tohoku 7. agric. Res. 6, 307.

Healy, M., McLaren, A. \& Michie, D. (1960) Foetal growth in the mouse. Proc. roy. Soc. B, 153, 367.

Huggetr, A. Sr. G. \& Pritchard, J. J. (1944) Experimental foetal death: the surviving placenta. Proc. R. Soc. Med. 38, 261.

McCANCE, R. A. (1962) Food, growth and time. Lancet, ii, 621.

McGarthy, J. G. (1963) Analysis of heterosis in mouse crosses. Thesis, Edinburgh.

Mclaren, A. \& Michie, D. (1959a) The spacing of implantations in the mouse uterus. Mem. Soc. Endocrinol. 6, 65.

McLaren, A. \& Michie, D. (1959b) Superpregnancy in the mouse. 1. Implantation and foetal mortality after induced super-ovulation in females of various ages. F. exp. Biol. 36, 281.

MaLaren, A. \& Mrchie, D. (1960a) Congenital runts. Ciba Foundation Symposium on Congenital Malformations, pp. 178-194.

MaLaren, A. \& Michie, D. (1960b) Control of pre-natal growth in mammals. Nature, Lond. 187, 363.

McLaren, A. \& Mrchie, D. (1963) Nature of the systemic effect of litter size on gestation period in mice. 7. Reprod. Fertil. 6, 139.

Rodbard, S. \& Katz, L. N. (1944) The effect of pregnancy on blood pressure in normotensive and hypertensive dogs. Amer. 7. Obstet. Gynec. 47, 753.

Rosahn, P. D. \& GReEne, H. S. N. (1936) The influence of intrauterine factors on the fetal weight of rabbits. F. exp. Med. 63, 901 .

Sugryama, T. (1961) Morphological studies on the placenta of mice of various ages and strains. 1. Variation in fetal and placental weight at term. Acta Med. Univ. Kioto, 37, 139.

Vetulani, T. (1930) Inheritance of body weight and of certain dimensions in new-born mice. (Polish with English summary). Mém. Inst. Nat. Polon. Econ. Rur. Pulawy, 11, 456.

Waldorf, D. P., Foote, W. C., Self, H. L., Ghapman, A. B. \& Casida, L. E. (1957) Factors affecting fetal pig weight late in gestation. F. Anim. Sci. 16, 976. 